\title{
PELATIHAN PENINGKATAN KEMAMPUAN GURU DALAM PEMBELAJARAN MATEMATIKA DI MADRASAH IBTIDAIYAH SE-KECAMATAN TAMBANG KABUPATEN KAMPAR
}

\author{
Fitri Aryani ${ }^{1}$, Corry Corazon Marzuki ${ }^{1}$ dan Irma Suryani ${ }^{1}$ \\ ${ }^{1}$ Jurusan Matematika, UIN Sultan Syarif Kasim Riau \\ khodijah_fitri@uin-suska.ac.id, corry@uin-suska.ac.id,irma.suryani@uin-suska.ac.id
}

\begin{tabular}{l} 
Info Artikel \\
\hline Riwayat Artikel: \\
Diterima: April 2018 \\
Direvisi: Agustus 2019 \\
Diterbitkan: September 2019
\end{tabular}

\section{Keywords:}

Gasing Method

Teacher Madrasah Ibtidaiyah

Tambang District

t Distribution

\begin{abstract}
This paper contains the results of community service conducted by the implementation team of Madrasah Ibtidaiyah teachers in Tambang District, Kampar Regency. Here the community service team wants to improve the ability of teachers to provide teaching and understanding of mathematics to students later by using the GASING Method. The results obtained that there was an increase in the teachers present as participants by looking at the results of the pretest and post-test that have been done. This result can be seen that starting with $\mathrm{H}_{0}$, that is, significant pre-test scores are smaller than post-test scores. That is, the teachers who attended were faster and more precise in answering the questions given than before they knew GASING.
\end{abstract}

Copyright $($ C) 2019 JRCE. All rights reserved.

\section{Korespondensi:}

Fitri Aryani,

UIN Sultan Syarif Kasim Riau,

J1. Subrantas Km. 15, Pekanbaru, Indonesia 28293

khodijah_fitri@uin-suska.ac.id

\section{PENDAHULUAN}

Matematika merupakan salah satu mata pelajaran yang menjadi momok bagi sebagian besar siswa, baik siswa SD, SMP, dan SMA, bahkan sampai Perguruan Tinggi. Salah satu penyebab hal ini adalah proses pembelajaran yang cenderung menghafalkan konsep-konsep matematika dan kurangnya pemaknaan terhadap materi pembelajaran matematika. Selain itu, proses pembelajaran matematika lebih banyak melalui penjelasan secara langsung oleh guru yang didominasi dengan pemberian ceramah. Akibatnya, pembelajaran matematika menjadi kurang bermakna dan membosankan, sehingga siswa malas untuk belajar. Apabila siswa sudah malas untuk belajar, mereka akan banyak ketinggalan materi pelajaran. Semakin banyak ketinggalan materi pelajaran, mereka akan semakin tidak paham materi pelajaran dan semakin malas belajar matematika.

Banyak faktor yang mempengaruhi motivasi dan prestasi belajar siswa di bidang matematika. Salah satu faktor yang sangat berpengaruh adalah cara penyajian materi oleh guru. Cara penyajian materi ini sangat berkaitan dengan kompetensi yang dimiliki guru.

Lembaga pendidikan yang setara dengan Sekolah Dasar yang berada di bawah Kementerian Agama diberi nama Madrasah Ibtidaiyah. Di Kecamatan Tambang Kabupaten Kampar terdapat sekitar 5 Madrasah Ibtidaiyah, dimana madrasah-madrasah tersebut berstatus swasta.

Beberapa informasi mengenai kondisi pembelajaran matematika di Madrasah - madrasah Ibtidaiyah se-Kecamatan Tambang Kabupaten Kampar sebagai berikut : 
a. Sebagian besar guru matematika di Madrasah - madrasah Ibtidaiyah di Kecamatan Tambang Kabupaten Kampar tidak berlatar belakang pendidikan matematika ataupun PGSD. Disamping itu, motivasi para guru untuk mengembangkan inovasi pembelajaran juga sangat rendah karena jarang mengikuti kegiatan-kegiatan ilmiah. Oleh karena itu, perlu dilakukannya peningkatan kompetensi matematika guru Madrasah Ibtidaiyah di Kecamatan Tambang Kabupaten Kampar.

b. Metode maupun pendekatan pembelajaran matematika yang diterapkan oleh guru tampaknya bersifat monoton, kurang variatif, dan didominasi dengan pemberian ceramah, sehingga siswa kurang aktif dan bosan.

c. Pemanfaatan LKS dalam pembelajaran hanya sebatas sebagai bahan untuk mengerjakan soal latihan, menyebabkan siswa hanya mencoba menyelesaikan soal-soal sesuai dengan contoh yang tertuang pada LKS.

Dari beberapa kondisi dan fakta yang sudah dipaparkan di atas, maka diperlukan adanya pelatihan untuk meningkatkan kemampuan matematika guru Madrasah Ibtidaiyah di Kecamatan Tambang Kabupaten Kampar. Oleh karena itu, tim pelaksana Pengabdian kepada Masyarakat ini berinisiatif untuk melakukan pelatihan mengenai cara mudah pengurangan dan pembagian menggunakan metode GASING (gampang, asik, dan menyenangkan). Pelatihan ini adalah kelanjutan dari pelatihan yang sudah dilakukan pengabdi pada Tahun 2016, yaitu mengenai cara mudah penjumlahan dan perkalian menggunakan metode GASING.

Berdasarkan hasil evaluasi terhadap pelatihan yang diadakan pada tahun 2016 tersebut diperoleh bahwa metode GASING ini dapat meningkatkan kemampuan matematika guru Madrasah Ibtidaiyah di Kecamatan Tambang Kabupaten Kampar. Hal ini dilihat dari kecepatan mereka dalam menyelesaikan soal matematika terkait pengurangan dan pembagian pada pre-test dan post-test yang dilakukan pada pelatihan tersebut.

Pengajaran Matematika GASING atau Gampang Asyik dan Menyenangkan adalah salah satu metode pengajaran matematika yang diciptakan oleh Prof. Yohanes Surya, Ph.D. Beliau adalah seorang fisikawan yang lebih dikenal dengan kiprahnya dalam TOFI (Tim Olimpiade Fisika Indonesia). Melalui wadah TOFI ini, beliau membawa anak-anak Indonesia memenangkan berbagai kompetisi olimpiade Nasional, Regional dan Internasional. Metode Gasing merupakan metode yang sangat ringan, mudah dipahami oleh berbagai kalangan dan sangat menyenangkan dalam prakteknya.

Prof. Yohanes Surya, Ph.D. sudah sering menerapkan metode GASING ini kepada anak-anak di daerah terpencil yang mendapatkan pendidikan yang tidak memadai. Setelah dilakukan penelitian, ternyata metode ini dapat membuat mereka mampu menyelesaikan persoalan matematika lebih cepat daripada seorang berpendidikan tinggi tetapi belum mengenal metode GASING.

Berdasarkan latar belakang tersebut, maka tim pengabdi tertarik untuk melakukan pelatihan metode GASING kepada guru-guru Madrasah Ibtidaiyah di Kecamatan Tambang Kabupaten Kampar, yaitu mengenai materi pengurangan dan pembagian.

Setelah diadakannya pelatihan ini diharapkan kemampuan matematika guru dapat meningkat dan guru dapat meningkatkan penalaran dan pemahaman siswa. Hal ini diharapkan dapat meningkatkan motivasi dan minat belajar siswa. Sehingga pelatihan ini dapat berkontribusi untuk meningkatkan kualitas pendidikan di Propinsi Riau, khususnya Kabupaten Kampar.

\section{METODE PENELITIAN}

Untuk mengatasi permasalahan di Madrasah-madrasah Ibtidaiyah se-Kecamatan Tambang Kabupaten Kampar seperti yang telah dijelaskan di atas, maka tim pelaksana Pengabdian kepada Masyarakat ini akan mengadakan kegiatan Pelatihan Metode GASING (Gampang, Asik, dan Menyenangkan).

Metode GASING adalah suatu metode pembelajaran matematika dengan langkah demi langkah yang membuat anak menguasai matematika secara gampang, asyik dan menyenangkan. Kunci metode GASING ini adalah proses langkah demi langkah, yang disusun sedemikian rupa sehingga penguasaan materi dibangun dari pemahaman materi sebelumnya. Pentingnya proses langkah demi langkah ini dalam metode GASING tercermin sewaktu anak-anak belajar suatu topik, ada titik kritis yang harus mereka lewati. Setelah mencapai titik kritis ini mereka tidak akan sulit lagi mengerjakan soal dalam topik tersebut.

Dalam pembelajaran metode GASING ini anak-anak diajak bermain dan bereksplorasi dengan alat peraga sehingga benar-benar terasa dan terbayang konsep yang ingin disampaikan. Jadi yang abstrak selalu diawali dengan sesuatu yang konkrit, sehingga anak-anak dapat jauh lebih mudah mengerti dan mengaplikasikan konsep yang diajarkan. Salah satu ciri khas lain dari metode GASING adalah anak-anak dapat melakukan perhitungan di luar kepala (mencongak) dengan cepat.

Pelatihan ini dibagi atas tiga sesi, yaitu materi mengenal bilangan, materi penjumlahan dan materi perkalian. Pelatihan ini diharapkan dapat membantu memudahkan guru dalam mengajarkan penjumlahan dan perkalian kepada siswa, dan siswa juga dapat dengan mudah mengerti materi tersebut. 
Tim pelaksana Pengabdian kepada Masyarakat ini akan melaksanakan pelatihan ini di UPTD Kecamatan Tambang dengan mengundang guru-guru Madrasah Ibtidaiyah di Kecamatan Tambang. Tim pelaksana akan melakukan tiga kali kunjungan yang terdiri dari satu kali kunjungan untuk tahap sosialisasi kegiatan dan dua kali kunjungan untuk pelaksanaan pelatihan. Guru yang akan diundang berasal dari lima Madrasah Ibtidaiyah di Kecamatan Tambang Kabupaten Kampar, yaitu MIS Muhammadiyah Pulau Tengah, MIS Muhammadiyah Aur Sati, MIS Al-abrar, MIS Darussalam, dan MIS Al-Madani.

\section{HASIL DAN PEMBAHASAN}

Pelaksanaan pengabdian kepada masyarakat dilakukan dalam bentuk pelatihan/training.Tim pelaksana Pengabdian kepada Masyarakat telah melakukan kegiatan Pelatihan Metode GASING (Gampang, Asik, dan Menyenangkan) untuk guru-guru Madrasah Ibtidaiyah se-Kecamatan Tambang Kabupaten Kampar di UPTD Kecamatan Tambang.

Pelatihan ini dibagi atas tiga sesi, yaitu materi mengenal bilangan, materi penjumlahan, dan materi perkalian. Rencananya sesi I dan II (materi mengenal bilangan dan materi penjumlahan) akan dilaksanakan pada tanggal 10 November 2016 pukul 09.00-13.00 WIB. Sedangkan sesi III (materi perkalian) akan dilaksanakan pada tanggal 17 November 2016 pukul 09.00-11.00 WIB. Namun, berdasarkan kesepakatan tim pengabdian dan peserta, pelatihan ini dijadikan satu hari, yaitu tanggal 10 November 2016 pukul 09.00-16.00 WIB yang dibagi menjadi tiga sesi. Sesi I (materi mengenal bilangan) dilaksanakan pukul 09.00-10.30 WIB. Sesi II (materi penjumlahan) dilaksanakan pukul 10.30-12.00 WIB dan dilanjutkan pukul 13.00-13.30 WIB. Sedangkan sesi III (materi perkalian) dilaksanakan pada pukul 13.30-16.00 WIB.

Peserta Pengabdian kepada Masyarakat ini adalah guru-guru Madrasah Ibtidaiyah di Kecamatan Tambang. Guru-guru tersebut berasal dari lima Madrasah Ibtidaiyah di Kecamatan Tambang Kabupaten Kampar, yaitu MI Muhammadiyah Pulau Tengah, MI Muhammadiyah Aur Sati, MIS Al-abrar, MI Darussalam, dan MI Assalwa. Jumlah peserta yang hadir pada sesi I adalah 18 orang, sesi II ada 15 orang, dan sesi III ada 14 orang.

Adapun tahapan pelatihan yang telah dilakukan adalah sebagai berikut.

a. Narasumber sesi I menjelaskan cara mengenalkan bilangan kepada siswa. Kegiatan ini lebih bersifat interaktif karena lebih banyak mengajak para peserta untuk aktif dalam mempraktekkan teori-teori yang sudah disampaikan.

b. Peserta diberikan soal pre-test mengenai materi penjumlahan. Peserta diberi waktu 5 menit untuk mengerjakannya. Kemudian tim pengabdi memeriksa berapa soal yang dapat dijawab dengan benar.

c. Narasumber sesi II menjelaskan cara mudah menjumlahkan satu angka dengan satu angka, dua angka dengan satu angka, dua angka dengan dua angka secara bersusun, dua angka atau lebih, dan penjumlahan banyak bilangan satu angka (sistem coret), serta penjumlahan banyak bilangan yang lebih dari satu angka (sistem coret). Kegiatan ini lebih bersifat interaktif karena lebih banyak mengajak para peserta untuk aktif dalam mempraktekkan teori-teori yang sudah disampaikan.

d. Peserta diberikan soal pre-test mengenai materi perkalian. Peserta diberi waktu 7 menit untuk mengerjakannya. Kemudian tim pengabdi memeriksa berapa soal yang dapat dijawab dengan benar.

e. Narasumber sesi III menjelaskan makna perkalian, cara mudah menghafal perkalian, cara mudah perkalian dua angka dengan satu angka, dua angka dengan dua angka, tiga angka dengan dua angka, dan tiga angka dengan tiga angka. Kegiatan ini lebih bersifat interaktif karena lebih banyak mengajak para peserta untuk aktif dalam mempraktekkan teori-teori yang sudah disampaikan.

f. Peserta diberikan soal post-test mengenai materi penjumlahan. Peserta diberi waktu 5 menit untuk mengerjakannya. Kemudian tim pengabdi memeriksa berapa soal yang dapat dijawab dengan benar.

g. Peserta diberikan soal post-test mengenai materi perkalian. Peserta diberi waktu 7 menit untuk mengerjakannya. Kemudian tim pengabdi memeriksa berapa soal yang dapat dijawab dengan benar.

Selama melakukan pengabdian kepada masyarakat, tim pelaksana telah melakukan tiga kali kunjungan yang terdiri dari satu kali kunjungan untuk tahap sosialisasi kegiatan, satu kali kunjungan untuk pelaksanaan pengabdian, dan satu kali kunjungan untuk menyampaikan hasil evaluasi pelaksanaan pelatihan.

Sebelum penyampaian materi pelatihan, peserta diberikan soal pre-test untuk melihat kemampuan awal para peserta pelatihan mengenai materi penjumlahan dan perkalian. Setelah diberikan pelatihan, peserta diberikan lagi soal post-test untuk melihat peningkatan kemampuan peserta setelah mendapatkan pelatihan ini. Soal post-test ini adalah soal yang sama dengan soal pre-test. 
Tim pengabdi berharap nilai post-test yang mereka dapatkan lebih baik daripada nilai pre-test. Adapun hasil pre-test dan post-test untuk materi penjumlahan yang diperoleh oleh para peserta pelatihan disajikan pada tabel berikut.

\begin{tabular}{|l|c|c|c|c|}
\multicolumn{4}{c}{ Tabel 1. Hasil Pre-test dan Post-test Peserta } \\
\hline \multirow{4}{*}{ No } & \multicolumn{2}{|c|}{$\begin{array}{c}\text { Materi } \\
\text { Penjumlahan } \\
\text { (100 soal) }\end{array}$} & \multicolumn{2}{c|}{$\begin{array}{c}\text { Materi } \\
\text { Perkalian (125 } \\
\text { soal) }\end{array}$} \\
\cline { 2 - 5 } & $\begin{array}{c}\text { Nilai } \\
\text { Pre-test }\end{array}$ & $\begin{array}{c}\text { Nilai } \\
\text { Post-test }\end{array}$ & $\begin{array}{c}\text { Nilai } \\
\text { Pre-test }\end{array}$ & $\begin{array}{c}\text { Nilai } \\
\text { Post-test }\end{array}$ \\
\hline 1. & 70 & 84 & 71 & 86 \\
2. & 90 & 90 & 95 & 87 \\
3. & 98 & 99 & 108 & 110 \\
4. & 83 & 88 & 107 & 104 \\
5. & 88 & 96 & 106 & 109 \\
6. & 91 & 90 & 106 & 111 \\
7. & 78 & 76 & 94 & 95 \\
8. & 86 & 87 & 102 & 108 \\
9. & 91 & 92 & 111 & 114 \\
10. & 47 & 80 & 87 & 100 \\
11. & 59 & 66 & 48 & 91 \\
12. & 78 & 82 & 45 & 53 \\
13. & 83 & 82 & 68 & 107 \\
& & & & \\
\hline
\end{tabular}

Data pada Tabel 1 dapat direpresentasikan dalam bentuk grafik berikut.

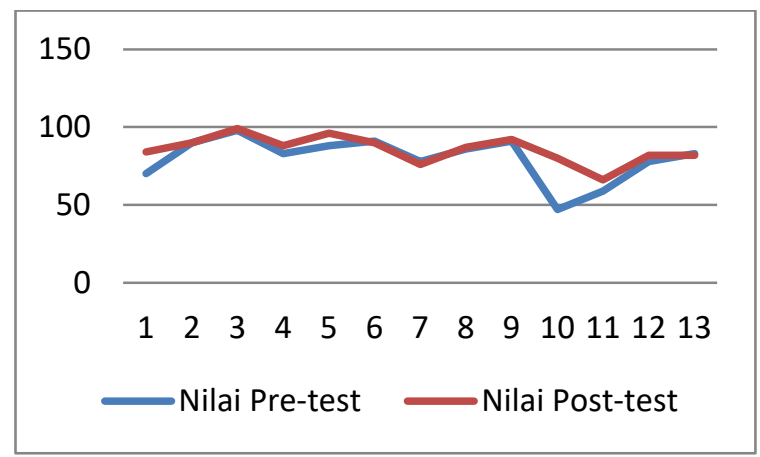

\section{Gambar 1. Perbandingan Nilai Pre-test dan Post-test Penjumlahan}

Berdasarkan Gambar 1 dapat dilihat bahwa hampir semua peserta mengalami kenaikan nilai dari pre-test ke post-test pada materi penjumlahan.

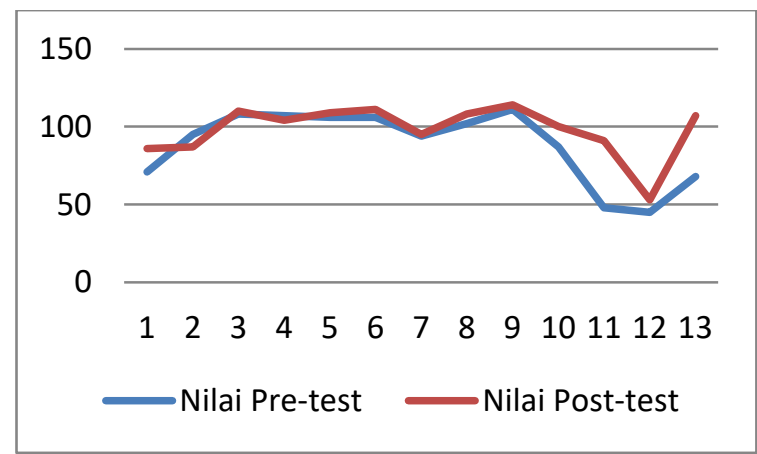

Gambar 2. Perbandingan Nilai Pre-test dan Post-test Perkalian

Berdasarkan Gambar 2 dapat dilihat bahwa hampir semua peserta juga mengalami kenaikan nilai dari pre-test ke post-test pada materi perkalian. 
Namun, untuk menguji secara ilmiah apakah pelatihan yang diberikan ini memang bermanfaat untuk meningkatkan kemampuan guru pada materi penjumlahan dan perkalian, maka nilai pre-test dan post-test ini akan diuji menggunakan uji nilai tengah data berpasangan.

Berikut akan dilakukan pengujian hipotesis apakah terdapat peningkatan yang signifikan setelah dilakukan pelatihan mengenai materi penjumlahan.

Misalkan $\mu_{1}$ dan $\mu_{2}$ adalah nilai rata-rata pre-test penjumlahan dan nilai rata-rata post-test penjumlahan. Langkah-langkah pengujiannya adalah sebagai berikut.

1. $H_{0}: \mu_{1}=\mu_{2}$ atau $\mu_{D}=\mu_{1}-\mu_{2}=0$

2. $H_{1}: \mu_{1}<\mu_{2}$ atau $\mu_{D}=\mu_{1}-\mu_{2}<0$

3. $\alpha=0.05$

4. Wilayah kritik : $t<-t_{\alpha}=-1,782$, yang dalam hal ini $t=\frac{\bar{d}}{s_{d} / \sqrt{n}}$.

5. Perhitungan :

\begin{tabular}{|c|c|c|c|}
\hline $\begin{array}{l}\text { Nilai Pre- } \\
\text { test }\end{array}$ & $\begin{array}{l}\text { Nilai } \\
\text { Post-test }\end{array}$ & $d_{i}$ & $d_{i}{ }^{2}$ \\
\hline 70 & 84 & -14 & 196 \\
90 & 90 & 0 & 0 \\
98 & 99 & -1 & 1 \\
83 & 88 & -5 & 25 \\
88 & 96 & -8 & 64 \\
91 & 90 & 1 & 1 \\
78 & 76 & 2 & 4 \\
86 & 87 & -1 & 1 \\
91 & 92 & -1 & 1 \\
47 & 80 & -33 & 1089 \\
59 & 66 & -7 & 49 \\
78 & 82 & -4 & 16 \\
83 & 82 & 1 & 1 \\
\hline
\end{tabular}

Berdasarkan tabel diatas diperoleh $\bar{d}=-\frac{70}{13}=-5,38$ dan $s_{d}{ }^{2}=\frac{13 \cdot \sum_{i=1}^{13} d_{i}{ }^{2}-\left(\sum_{i=1}^{13} d_{i}\right)^{2}}{13 .(13-1)}=$ $\frac{13.1448-(-70)^{2}}{13.12}=89,256$ atau $s_{d}=9,45$.

Sehingga didapatkan $t=\frac{-5,38}{9,45 / \sqrt{13}}=-2,05$

6. Keputusan : Karena $t=-2,05<-1,782=-t_{\alpha}$ maka tolak $H_{0}$ dan disimpulkan bahwa nilai ratarata pre-test penjumlahan signifikan lebih kecil dibandingkan nilai rata-rata post-test penjumlahan.

Selanjutnya akan dilakukan pengujian hipotesis apakah terdapat peningkatan yang signifikan setelah dilakukan pelatihan mengenai materi perkalian.

Misalkan $\mu_{1}$ dan $\mu_{2}$ adalah nilai rata-rata pre-test perkalian dan nilai rata-rata post-test perkalian. Langkah-langkah pengujiannya adalah sebagai berikut.

1. $H_{0}: \mu_{1}=\mu_{2}$ atau $\mu_{D}=\mu_{1}-\mu_{2}=0$

2. $H_{1}: \mu_{1}<\mu_{2}$ atau $\mu_{D}=\mu_{1}-\mu_{2}<0$

3. $\alpha=0.05$

4. Wilayah kritik : $t<-t_{\alpha}=-1,782$, yang dalam hal ini $t=\frac{\bar{d}}{s_{d} / \sqrt{n}}$.

5. Perhitungan :

\begin{tabular}{|c|c|c|c|}
\hline $\begin{array}{l}\text { Nilai Pre- } \\
\text { test }\end{array}$ & $\begin{array}{l}\text { Nilai } \\
\text { Post-test }\end{array}$ & $d_{i}$ & $d_{i}{ }^{2}$ \\
\hline 71 & 86 & -15 & 225 \\
95 & 87 & 8 & 64 \\
108 & 110 & -2 & 4 \\
107 & 104 & 3 & 9 \\
106 & 109 & -3 & 9 \\
106 & 111 & & \\
\hline
\end{tabular}




\begin{tabular}{|c|c|c|c|}
\hline 94 & 95 & -5 & 25 \\
102 & 108 & -1 & 1 \\
111 & 114 & -6 & 36 \\
87 & 100 & -3 & 9 \\
48 & 91 & -13 & 169 \\
45 & 53 & -43 & 1849 \\
68 & 107 & -8 & 64 \\
& & -39 & 1521 \\
\hline & & -127 & 3985 \\
\hline
\end{tabular}

Berdasarkan tabel diatas diperoleh $\bar{d}=-\frac{127}{13}=-9,77$ dan

$s_{d}^{2}=\frac{13 \cdot \sum_{i=1}^{13} d_{i}{ }^{2}-\left(\sum_{i=1}^{13} d_{i}\right)^{2}}{13 .(13-1)}=\frac{13.3985-(-127)^{2}}{13.12}=228,6923$ atau $s_{d}=15,1$.

Sehingga didapatkan $t=\frac{-9,77}{15,1 / \sqrt{13}}=-2,329$

Keputusan : Karena $t=-2,329<-1,782=-t_{\alpha}$ maka tolak $H_{0}$ dan disimpulkan bahwa nilai rata-rata pre-test perkalian signifikan lebih kecil dibandingkan nilai rata-rata post-test perkalian.

Kegiatan Pengabdian kepada Masyarakat ini bertujuan untuk meningkatkan kemampuan matematika guru Madrasah Ibtidaiyah di Kecamatan Tambang Kabupaten Kampar. Kegiatan ini berbentuk Pelatihan Metode Gasing untuk meningkatkan kemapuan matematika guru khususnya mengenai penjumlahan dan perkalian. Sebelum dan sesudah pelatihan, peserta diberikan soal pre-test dan post-test. Berdasarkan hasil pre-test dan post-test tersebut dapat disimpulkan bahwa pelatihan ini dapat meningkatkan kemampuan matematika guru khususnya dalam penjumlahan dan perkalian.

\section{KESIMPULAN}

Berdasarkan hasil pembahasan diperoleh bahwa:

1. Nilai rata-rata pre-test penjumlahan signifikan lebih kecil dibandingkan nilai rata-rata post-test penjumlahan

2. Nilai rata-rata pre-test perkalian signifikan lebih kecil dibandingkan nilai rata-rata post-test perkalian

Dengan demikian dapat disimpulkan bahwa pelatihan yang telah dilakukan dapat meningkatkan kemampuan matematika guru Madrasah Ibtidaiyah di Kecamatan Tambang Kabupaten.

\section{UCAPAN TERIMAKASIH}

Ucapan terimakasih kepada LPPM UIN Suska Riau yang telah mendanai kegiatan pengabdian kepada masyarakat ini sehingga dapat terlaksana dengan baik.

\section{DAFTAR PUSTAKA}

Pujiati dan Sigit. 2009. Pembelajaran Pengukuran Luas Bangun Datar dan Volum Bangun Ruang di SD, Sleman, Departemen Pendidikan Nasional.

Tim Karya Guru. 2007. Terampil Berhitung Matematika Untuk SD Kelas III, Erlangga. Sulardi. 2008. Pandai Berhitung Matematika Untuk SD Kelas III. Erlangga.

Sulardi. 2008. Pandai Berhitung Matematika Untuk SD Kelas V. Erlangga. Sulardi. 2008. Pandai Berhitung Matematika Untuk SD Kelas VI. Erlangga.

Tim Karya Guru. 2014.Terampil Berhitung Matematika Untuk SD Kelas V. Erlangga.

Surya Yohanes. Buku Petunjuk Guru Pintar Berhitung Gasing. Surya Institute. 